\title{
Should drill or shouldn't drill? Urban and rural dwellers' acceptance of geothermal power plant in Mount Slamet protection forest, Indonesia
}

\author{
Dhifa Qorizki ${ }^{1}$, Dwiko B. Permadi ${ }^{1 *}$, Teguh Yuwono ${ }^{1}$, and Rohman ${ }^{1}$ \\ 1 Forest Management Department, Faculty of Forestry, Universitas Gadjah Mada, Yogyakarta, Indonesia \\ * Correspondence author: dwikopermadi@yahoo.com; dbpermadi@ugm.ac.id ; Tel. +6282328606218
}

\begin{abstract}
Geothermal is one of the new renewable energy, which is more environmentally friendly than the existing fossil energy and has great potential to become an alternative source of energy in the future. However, the level of social acceptance of geothermal power plants operating in forest areas has not been widely studied. This study aims to reveal the social acceptance of affected residents toward the exploration of Baturaden geothermal power plant, operating in the protection forest area of Mount Slamet. The survey was conducted online to indirectly affected residents living mostly in Banyumas urban areas, while the offline face-to-face survey was administered to the directly affected residents in Sambirata and Karang Tengah villages. A total of 286 samples were analyzed. It was found that the majority of respondents preferred not to continue the establishment of the geothermal power plant, but both rural and urban dwellers have distinctive responses and reasonings. The rural tended to have stronger rejection compared to the urban residents. The acceptance of the project in both groups combined was motivated mainly by the prospect of electricity from more environmentally friendly energy sources and compliance to government policy. Those who refused tend to see from the negative impacts on the disruptions of the daily livelihood in rural areas and environmental damages. Three attitude factors significantly affect the continuation of drilling operation of GPP, namely: economic prospects of geothermal utilization in protection forests, technological optimism to migate the engative impacts, and perceived environmental concerns. To increase the social acceptance, it is suggested that policy makers and energy industry players should integrate the mitigation measures by using more proper technology within the project budget and act harmoniously to increase public awareness of the use of renewable and cleaner energy as well as pay attention to the health, welfare and culture of the local community.
\end{abstract}

Keywords: Social acceptance; Renewable energy; Strategic environmental assessment; Logistic regression; Forest utilization policy

\section{Introduction}

Geothermal is one of the new and renewable energy sources that is more environmentally friendly than the existing fossil energy and has a prospective use to become an alternative energy source in the future (Latifah \& Gusmayanti, 2012; Setiawan, 2012). Based on Law No. 21/2014 on Geothermal Energy Article 24, the Government of Indonesia has classified geothermal as a forest environmental service that can be utilized for national interests with two mechanisms. The first mechanism is in the form of lease-to-use forest area permits in protected and production forest areas, while the second mechanism is an environmental service utilization permit (IPJL) if it is in a conservation forest area.

Until 2014, the Geological Agency identified 312 geothermal hotspots in Indonesia with a potential of $28.910 \mathrm{MW}$, the second largest in the world after the United States (MEMR, 2015). Of them, a total of 154 geothermal hotspots are in forest areas, either production forests, protection forests or conservation forests (MOEF, 2015). The total potential of electrical energy that can be generated from the forest area is estimated at $16.441 \mathrm{MW}$ or $57 \%$ of the total potential of geothermal energy that can be generated in Indonesia. Currently, 13 out of the 17 geothermal power plant (GPP) that have been operating in Indonesia are in the forests. Based on Presidential Regulation Nr. 18/2020 on National Mid-term Development Plan 2020 - 2025 the number of new GPPs to be explored and exploited is 69 projects spread across Indonesia. 
On the forest areas of Java and Bali, geothermal is mostly found in protected forests, that is, 13 out of 33 points, with the potential to generate electricity of $2.996 \mathrm{MW}$ (MOEF, 2015). One of the permit for utilizing geothermal energy is Baturraden GPP, which is located in the protection forest of Mount Slamet. This power plant is estimated to produce $2 \times 110 \mathrm{MW}$ of electric power and is included in the phase II of the $10.000 \mathrm{MW}$ power plant acceleration phase (2015-2019). The total working area (WKP) of Baturraden GPP is 24.660 hectares, covering five regencies of Banyumas (15.490 hectares), Brebes (3.052 hectares), Tegal ( 874 hectares), Pemalang (2.345 hectares), and Purbalingga (2.900 hectares) (Central Java Governor Decree No. 541/27/2011 dated on 11 April 2011). Even so, only 137,5 hectares of land will be cleared for geothermal development and infrastructure.

Geothermal exploration carried out in the Mount Slamet protection forests has actually caused undesirable environmental and livelihood impacts. Based on mass media reports from November 2016 to March 2017 the Banyumas downstream residents began to experience an ecological disaster in the form of turbid water from the Prukut river. The watershed of Prukut river is used by the surrounding communities for daily activities such as agricultural, domestic, and tourism activities. In the tourism sector, the tourist manager of Cipendok Waterfall reported changes in the color of waterfall to be brown during those periods. This has an impact on decreasing tourist visits. Apart from that, in the fisheries sector, some aquaculture farmings also experience failure due to the fish not being able to survive in the cloudy, muddy water conditions. In the following rainy season, flash floods occurred on October 15, 2017, bringing soil, trees, rocks and debris coming from the upstream of Mount Slamet protection forest (Suara Merdeka, 2017). Through the mass media, the public assesses that the change in environmental conditions is due to the impact of exploration of Baturraden GPP.

The construction of GPP in protection forests requires a strategic environmental assessment (SEA) or Kajian Lingkungan Hidup Strategis (KLHS) based on the Ministry of Environment Regulation No. 5/2012, as it potentially has a broad impact on environmental sustainability and the livelihoods of many people. However, none of the GPP development in Indonesia has been equipped by a SEA document, which is required to incorporate in the prevailing spatial plans (Meijard et al., 2019). SEA is a series of systematic, comprehensive, and participatory analyses to ensure that the principles of sustainable development become the basis and are integrated in the development of an area and/or policies, plans and / or programs (PPP) based on Law No. 32/2009 on Protection and Management of the Environment. SEA is one of the policy instruments applied to assess the impact of whether a development of PPP will increase natural capital, human capital and social capital (MOE, 2008). SEA can be an ex-ante evaluation, which is carried out before a PPP is implemented, for example Regional Spatial Plan or Rencana Tata Ruang Wilayah (RTRW). It can also be done ex-post, that is, evaluating the PPP that has been running in the past as material for future development planning, such as the Regional Mid-term Development Plan or Rencana Pembangunan Jangka Menengah Daerah (RPJMD). SEA can also be applied to other PPPs other than RTRW and RPJMD, such as for projects to establish a cement factory in Kendeng and reclamation of the Jakarta North Coast. Thus, SEA should also be applied to the construction of a geothermal power plant (GPP) due to its strategic and having a broad impact. Unlike the environmental impact analysis (EIA), SEA is not intended to cancel or continue a PPP but to harmonize the social, economic, environmental and governance aspects of a PPP to meet the principles of sustainable development.

In the context of forest development planning, the forestry sector is a sub-system of the national and regional development system that must pay attention to other sub-systems including the social sub-system in the policy-making process (Simon, 2000). The social acceptance factor, both directly or indirectly affected residents by the construction of a GPP, is an important prerequisite for the goal of environmentally friendly and sustainable development. According to Cataldi (1999), social acceptance of the GPP project contains two contradicting meanings, the first is addressesing more attention on the economic benefits by certain sectors than on benefits for the people at large. The other focuses more on benefits for the environment and the public interests, which are greater than the interests of certain sectors. However, both of these meanings require efforts to minimize adverse impacts on the environmental or social aspects of the project site. 
In various publications, social acceptance of geothermal utilization has been studied quite a lot and is considered to have greatly influenced the adoption of the renewable energy program since the mid-20th century (Cataldi, 1999). For example, several studies of social acceptance of geothermal energy in the last ten years were carried out in Australia (Dowd et al., 2011; Romanach et al., 2015), European countries (Kępińska \& Kasztelewicz, 2015; Reith et al., 2013), Chile (Payera, 2018), Malaysia (Ahmad et al, 2014), China (Liu et al, 2018), and Japan (Kubota et al, 2013; Hymans \& Uchikoshi, 2021). In those studies, generally the adoption of GPP as an environmentally friendly renewbale energy is constrained by social acceptance in both developed and developing countries. Several factors influence people's attitudes towards geothermal, including the level of understanding and uncertainty about geothermal technology and the critical attitude of residents towards environmental impacts that may arise compared to long-term economic benefits.

This paper aims to assess the social acceptance of Baturaden GPP project located in the Mount Slamet protection forest, Central Java and the factors influencing it. The Baturaden GPP has not yet started in the area, but is still in an exploration phase aiming to asses the feasibility of the electrical power that can be generated in future. However, during exploration and drilling activities it has caused pros and cons among Banyumas residents due to unexpected environmental impacts, such as floods and landslides. This research is expected to contribute in increasing public participation for policy evaluation that is ex-post from the Baturaden GPP project and other similar projects. It is hoped that this knowledge of public voices can be utilized to improve policies, plans, or programs in SEA for the next GPP development or other similar policies elsewhere. In this paper, the presentation structure begins with an introduction, which is followed by research methods, presentation of the results, discussion and conclusion.

\section{Research Methods}

\subsection{Description of the study location}

Banyumas regency is one of the districts affected by the construction of a GPP operating in the protected forest of Mount Slamet, Central Java. This GPP has a very wide operational area (24.660 ha) located in the protected forest area of Baturaden and across five districts. The Mount Slamet protection forest stores typical flora and fauna that have been reported in different studies (Hoover et al., 2009; Kalima, 2007; Kusuma \& Astuti, 2009; Setiawan, et al., 2007; Widhiono, 2015). In there 40 plant species from 38 genera and 33 families at an altitude above 1.100 masl have been found. Kalima (2007) identifies tree species in this protected forest area, which are dominated by flowering trees, including Castanopsis argentea Blume, Elaeocarpus glaber Blume, Symplocos fasciculate Zoll., Ficus fistulosa Reinw, and Antidesma tetandrum Blume. Other information mentions the existence of unique (endemic) flora, such as the First Orchid (Macodes petola), Nepenthes (Nephenthes andrianii), Javanese Palm (Ceratolobus glaucescens), and Javanese areca nut (Pinanga javana). As well as endangered fauna, namely the Leopard (Panthera panlus), the Javan Suruli (Presbutis comata), the Javan gibbon (Hylobates molochi), the Bobcat (Prionailurus bengalensis), the Javanese Eagle (Spizaetus bartelsi), and the Deer (Muntiacus muntjak) (Kalima, 2007). In addition, as an area with $2^{\text {nd }}$ highest rainfall in Indonesia (Hoover et al., 2009), the protected forest of Mount Slamet has always wet soil conditions so that it is able to provide water supply through 7 large springs and 31 river flows that form the Serayu River Basin.

\subsection{Survey implementation}

The survey was conducted on Indonesian citizens who are domiciled in Banyumas District, occupied by 1.665000 people in 2019. We defined the number of samples using Slovin formula with margin of error $10 \%$, resulting in minimum 99 samples to be gathered in the survey. In total 286 samples were generated using both online and face-to-face survey. In this study, we differentiated the Banyumas residents into two sub-populations: those are directly affected and those who are not directly affected. Residents who are indirectly affected are residents who live in urban areas (in this research called urban dwellers) and are relatively far from the GPP exploration catchment area, so that they do not receive direct social, economic and environmental impacts on a daily basis. Meanwhile, residents who are directly affected are residents located in villages around the GPP 
operational area and who experience the social, economic and environmental impacts in their daily lives. The latter is called rural dwellers.

The online survey was administered for urban dwellers. The choice of the online survey method was considered appropriate for the urban people because of their ease of accessing information through the internet connection. The online survey was conducted by creating a google form page and distributed through social media networks: Facebook, Instagram, Twitter, and Whatsapp in February - March 2019. The online survey was limited to the following criteria: every individual who was at least 17 years old and currently resided in Banyumas district. From the online survey, 168 respondents completed the questionnaire, and they were identified living in 30 sub-districts scattered throughout the Banyumas regency. The proportion of these respondents who live around the city of Purwokerto (the district capital of Banyumas) was $45.8 \%$, while the rest were scattered in various other sub-districts capitals in Banyumas District.

Meanwhile, the face-to-face interview method is applied to those whose access to the internet were limited. In-person structured interviews were conducted in February - April 2019 in Sambirata and Karang Tengah villages, Cilongok sub-district, Banyumas district. The two villages were chosen because they were the entrance to the exploration activities and the closest villages to the location of GPP activities with a distance of approximately $15-20 \mathrm{~km}$. The sampling technique was a convenience sampling, that is, every head of the family who was met at his/her house at the time of the research was taken as a sample. The number of village heads interviewed were 120 respondents. However, only 118 respondents were able to completely answer the questions.

The questionnaire included questions about the approval of the GPP project plan (Q1: Do you agree with the GPP Baturaden project plan in the Mount Slamet protection forest?). It was continued with questions about the continuation of the project in the future (Q2: Should the Baturaden GPP project in the Mount Slamet protection forest be continued?). Respondents were allowed to answer yes, no and neither (refering to neutral or not know). The two questions are followed by open ended-questions about the reasons for choosing the answer. Respondents' interactions with various news sources commonly accessed as references to know the GPP project were also asked, such as online media, printed media, social media, direct observation, and outreach from project managers and the government. In addition, socio-demographic variables were also asked, such as age, gender, highest education, occupation, and monthly income with the minimum wage standard for Banyumas district.

Furthermore, respondents were given seventeen statements about the respondent's knowledge and attitudes towards renewable energy, protection forests, and the impacts of GPP that covered the level of seriousness of the threat of GPP exploration activities in daily life, flooding and erosion, biodiversity, social conflict, employment opportunity and agriculture (see Tabel 1). Each statement was given a response choice with a five Likert scale. With regard to knowledge statements (X1 to X6), score 1 indicated the least level of knowledge while 5 indicated the highest level of knowledge. Meanwhile, related to attitude statements (X7 - X17), score 1 indicated the highest disagreement level, whereas 5 indicated the highest approval level. A score of 3 indicated neutral. The details of each statement can be seen in Table 1.

Table 1. Formulation of statements of attitudes regarding GPP development in protection forest

\begin{tabular}{|c|l|}
\hline Code & \multicolumn{1}{|c|}{ The Statement } \\
\hline X1 & Geothermal energy is a renewable energy source that is environmentally friendly. \\
\hline X2 & $\begin{array}{l}\text { Most of the potential for geothermal energy needs to be utilized even though it is in } \\
\text { protection forest areas. }\end{array}$ \\
\hline X3 & $\begin{array}{l}\text { Protected forests have the main function of regulating water management, preventing } \\
\text { flooding, controlling erosion, preventing sea water intrusion, and maintaining soil } \\
\text { fertility. }\end{array}$ \\
\hline X4 & The local government approved the Baturraden GPP development policy. \\
\hline X5 & Baturaden GPP has changed in the color of the water in the Prukut river. \\
\hline X6 & Baturaden GPP has caused the big flood that happened recently. \\
\hline X7 & The construction of the Baturraden GPP will not disturb forest sustainability. \\
\hline X8 & Feeling the threat of erosion and landslides due to clearing of protected forest lands. \\
\hline
\end{tabular}




\begin{tabular}{|c|c|}
\hline Code & The Statement \\
\hline X9 & $\begin{array}{l}\text { Feeling that there is no threat of changing the color of the water in several river flows in } \\
\text { Banyumas Regency. }\end{array}$ \\
\hline $\mathrm{X} 10$ & $\begin{array}{l}\text { The construction of the Baturraden GPP project does not reduce the quality of the } \\
\text { environment, especially biodiversity and water management. }\end{array}$ \\
\hline $\mathrm{X} 11$ & $\begin{array}{l}\text { Changes in the color of water in several streams headed up from the Mount Slamet will } \\
\text { not disturb the availability of clean water for household needs. }\end{array}$ \\
\hline $\mathrm{X} 12$ & $\begin{array}{l}\text { The Baturraden GPP project has supported the improvement of public facilities, such as } \\
\text { education, health, roads, bridges, places of worship, etc. }\end{array}$ \\
\hline $\mathrm{X} 13$ & $\begin{array}{l}\text { The construction of the Baturraden GPP project did not cause conflict between } \\
\text { communities. }\end{array}$ \\
\hline $\mathrm{X} 14$ & $\begin{array}{l}\text { The construction of the Baturraden GPP project does not cause conflict between the } \\
\text { community and the managing company and / or the government. }\end{array}$ \\
\hline $\mathrm{X} 15$ & The change in the color of the river water does not reduce people's income. \\
\hline $\mathrm{X} 16$ & The construction of the Baturaden GPP project has not damaged people's agriculture. \\
\hline $\mathrm{X} 17$ & $\begin{array}{l}\text { The construction of the Baturraden GPP project opens new job and business } \\
\text { opportunities. }\end{array}$ \\
\hline
\end{tabular}

\subsection{Data analysis}

To analyse respondent's answer in open ended question, a qualitative data analysis was carried out following Miles and Habermas' method, that is, data reduction, data display, conclusion drawing and verification (Miles et al., 2014). The data reduction is a process of selection, simplification, abstraction and transformation of raw data of respondents' responses to open questions about the reasons they agreed or not to the continuation of the GPP. The reduction process resulted in new themes that were classified and then quantified their frequency and sorted according to the most frequently mentioned reasons to draw conclusion.

Descriptive statistical analysis was used to analyse and present information about the sociodemographic characteristics of the respondents and frequencies of respondents agreeing or not to the project continuation. Factor analysis was used to reduce the attitude variables presented in Table 1 into simpler factor. The generation of the number of simpler factors of attitude toward the project was based on the eigenvalue, which was greater than or equal to one. Factors having eigenvalue less than one was removed. The new factors was then tested using Chronbac alpha to see the internal consistency and then named based on the proponent statements.

Then logistic regression analysis was applied to determine the effect of new attitude factor variables and socio-demographic variables as independent variables on the dependent variable, namely the choice of respondents to agree or not the GPP project continuation. Logistic regression analysis was chosen because the dependent variable was dichotomous (Yes/No). Respondents who answered neutral or did not know were not included in the logistic regression analysis model. In data analysis, different types of people who were directly and indirectly affected by the project were modeled separately with the assumption that both were sub-populations with different characteristics.

\section{Results}

\subsection{Respondents' Socio-Demographic Characteristics}

The total respondents analyzed in this study were 286 samples, consisting of 118 samples (41.2\%) of rural dwellers who were collected through face-to-face surveys and 168 respondents (58.8\%) samples of urban dwellers who were collected through online surveys. The two types of samples have differences and similarities in terms of their socio-demographic characteristics. In general, the male sample number is larger than the female sample, however the urban subpopulation is slightly dominated by women $(61.9 \%)$ while the rural sub-population is dominated by men (56.8\%). The later could be household heads who were mostly men. The rural samples are dominated by two age classes, $26-35$ and $36-45$ years, totaling $61.9 \%$, while the urban samples are dominated by the post-millennial generation, namely the age class $17-25$ years, totaling $58.8 \%$. 
From the level of education, the majority of the rural is primary education graduates $(55.1 \%)$, while the urban is dominated by high school graduates (60.6\%). Both samples are dominated by residents whose income is less than the regional minimum wage (IDR $1.800 .000 /$ month), but in the same income class the number of urban who earn the same or more than the regional wage value is greater than the rural. In terms of occupation, as many as $53.4 \%$ of rural samples are dominated by farmers and unskilled laborers, while the urban are dominated by students and civil servants or employees (67.5\%). Table 2 describes the general characteristics of the respondents in the two samples.

Table 2. Characteristics of respondents based on the type of sample affected directly (rural) and indirectly (urban) by the project.

\begin{tabular}{|c|c|c|c|}
\hline Characteristics of Respondents & Rural samples & Urban samples & Total sample \\
\hline Number of respondents $(\mathrm{N})$ & $118(41.2)$ & $168(58.8)$ & $286(100)$ \\
\hline \multicolumn{4}{|l|}{ Gender: } \\
\hline - Male & $51(43.2)$ & $104(61.9)$ & $155(54.2)$ \\
\hline - Female & $67(56.8)$ & $64(38.1)$ & $131(45.8)$ \\
\hline \multicolumn{4}{|l|}{ Age } \\
\hline - $17-25$ years & $7(5.9)$ & $108(64.3)$ & $115(40.2)$ \\
\hline - $26-35$ years & $29(24.6)$ & $13(7.7)$ & $42(14.7)$ \\
\hline - $36-45$ years & $44(37.3)$ & $20(11.9)$ & 64 (22.4) \\
\hline - $46-55$ years & $22(18.6)$ & $27(16.1)$ & 49 (17.1) \\
\hline - $56-65$ years & $11(9.3)$ & $1(0.1)$ & $12(4.2)$ \\
\hline - $>65$ years & $7(5.9)$ & $0(0)$ & $7(2.4)$ \\
\hline \multicolumn{4}{|l|}{ Last Education Level } \\
\hline - No School & $10(8.4)$ & $0(0)$ & $10(3.5)$ \\
\hline $\begin{array}{ll}\text { - } & \text { Elementary } \\
& \text { School/Equivalent }\end{array}$ & $65(55.1)$ & $2(9.5)$ & $67(23.4)$ \\
\hline $\begin{array}{ll}- & \text { Junior High } \\
& \text { School/Equivalent } \\
\end{array}$ & $26(22.0)$ & $16(9.5)$ & $42(14.7)$ \\
\hline $\begin{array}{ll}- & \text { Senior High } \\
& \text { School/Equivalent }\end{array}$ & $16(13.6)$ & $102(60.6)$ & $118(41.3)$ \\
\hline - College & $1(0.9)$ & $48(28.4)$ & $49(17.1)$ \\
\hline \multicolumn{4}{|c|}{ Income (UMK district minimum wage standard, IDR 1.8 million / month) } \\
\hline$\bullet \quad<\mathrm{UMK}$ & $92(78.0)$ & $108(64.3)$ & $200(70.0)$ \\
\hline - $1-2 \times U M K$ & $24(20.3)$ & $45(26.8)$ & $69924.1)$ \\
\hline - $\quad>2 \times$ UMK & $2(1.7)$ & $15(8.9)$ & $17(5.9)$ \\
\hline \multicolumn{4}{|l|}{ Profession } \\
\hline - Student / College student & $2(1.7)$ & $67(39.9)$ & $69(24.1)$ \\
\hline $\begin{array}{ll} & \text { PNS / Employees / } \\
& \text { Devices } \\
\end{array}$ & $12(10.2)$ & $48(28.6)$ & $60(21.0)$ \\
\hline - Manual labor services & $31(26.3)$ & $12(7.1)$ & $43(15.0)$ \\
\hline $\begin{array}{l}\text { - Farmers / Ranchers / } \\
\text { Craftsmen }\end{array}$ & $32(27.1)$ & $8(4.8)$ & $40(14.0)$ \\
\hline $\begin{array}{ll}\text { - Entrepreneurial / } \\
\text { independent }\end{array}$ & $16(13.6)$ & $18(10.7)$ & $34(11.9)$ \\
\hline - $\quad$ Others / Not Working & $25(21.2)$ & $15(8.9)$ & $40(14.0)$ \\
\hline
\end{tabular}

\subsection{Respondents' Acceptance and Rejection of Geothermal Power Plants}

In general, Table 3 shows that, responding to the first question (Q1), $49.3 \%$ of the total respondents disagree with the GPP plan, while $33.2 \%$ of them agree, and the rest are neutral (17.5\%). Based on the types of affected residents, the result shows that the proportion of those who accept GPP projects in the rural samples is higher (39\%) than the urban samples (29.2\%). Therefore, 
the proportion of urban respondents rejecting the plan is higher (58.9\%) than that of rural (35.6\%). However, the proportion of respondents who answered neutral is higher for rural (25.4\%) than urban (11.9\%). These results indicate that the GPP development plan is more accepted by the rural dwellers than urban ones, although the majority of both groups clearly states their disagreement.

When it comes to the continuation of the development (Q2), the proportion of total respondents who prefer not to continue the plan is $52.1 \%$, while those who accept is just $22 \%$, and the neutral response is $25.9 \%$. Comparing responses of Q1 and Q2 for specific sample types, there is an increased resistance for the GPP development for rural respondents. This is the opposite of urban responses, where there is an increased votes for being neutral from $11.9 \%$ to $25.6 \%$, while the number of rejection decreases from $29.2 \%$ to $26.2 \%$. Thus, for rural residents, the occurrence of disasters following the GPP exploration may confirm their resistance to the project, while urban residents living outside the exploration area prefer to "wait and see" for the continuation of the project.

Table 3. Responds to community acceptance of the GPP project and its continuation

\begin{tabular}{|l|l|c|c|}
\hline \multirow{2}{*}{ Group/Question } & $\begin{array}{l}\text { Q1: Do you agree with the } \\
\text { Baturaden GPP project plan to be } \\
\text { carried out in protection forest? }\end{array}$ & $\begin{array}{l}\text { Q2: Should the Baturaden } \\
\text { GPP exploration project be } \\
\text { continued? }\end{array}$ \\
\hline \multirow{3}{*}{ Rural Samples } & Yes & $46(39.0)$ & $19(16.1)$ \\
\cline { 2 - 4 } & No & $42(35.6)$ & $68(57.6)$ \\
\cline { 2 - 4 } & Neutral & $30(25.4)$ & $31(26.3)$ \\
\cline { 2 - 4 } & Sub-total & $118(100)$ & $118(100)$ \\
\hline Urban Samples & Yes & $49(29.2)$ & $44(26.2)$ \\
\cline { 2 - 4 } & No & $99(58.9)$ & $81(48.2)$ \\
\cline { 2 - 4 } & Neutral & $20(11.9)$ & $43(25.6)$ \\
\cline { 2 - 4 } & Sub-total & $168(100)$ & $168(100)$ \\
\hline Total Samples & Yes & $95(33.2)$ & $63(22.0)$ \\
\cline { 2 - 4 } & No & $141(49.3)$ & $149(52.1)$ \\
\cline { 2 - 4 } & Neutral & $50(17.5)$ & $286(100)$ \\
\cline { 2 - 4 } & total & $286(100)$ & \\
\hline
\end{tabular}

Note: Figures in parentheses indicate the percentage (\%).

Respondents provide one and more reasons for choosing their response that can be reduced, classified and sorted. The reduction process produces seven main reasons for accepting the continuation of GPP project and ten reasons for rejecting it (See Table 4 and Table 5). In general, the main reason for accepting the project continuation are the positive expectation of a GPP, while those who reject is based on concerns about negative impacts on the preservation of protected forests and socio-economic losses for directly affected residents. Meanwhile, those who choose neutral still consider the positive benefits with the negative impact of the GPP's existence or their lack of awareness of the positive and negative impacts of the GPP project.

Table 4 presents details of the reasons for receiving the GPP project by the total samples and sub-sampels, namely: 1 ) supporting an increase in electricity supply and distribution in the future $(24.8 \%), 2)$ complying with central government policies $(20.2 \%), 3)$ supporting the use of new technology and renewable energy that is more environmentally friendly $(17.4 \%), 4)$ supporting regional economic development, national and social welfare $(16.5 \%)$, 5) availability of environmental impact mitigation (13.8\%), 6) supporting local employment (4.6\%), and 7) reducing fossil energy use (2.8\%).

Table 4. Respondents' reasons for supporting the GPP in the protected forest of Mount Slamet

\begin{tabular}{|c|c|c|c|}
\hline \multirow{2}{*}{ Main reasons for accepting } & \multicolumn{3}{|c|}{ Sample Responses } \\
\hline & Urban & Rural & Total \\
\hline 1. Supporting future electricity supply and distribution & $9(20.5)$ & $18(27.7)$ & $27(24.8)$ \\
\hline $\begin{array}{l}\text { 2. Supporting new, renewable and environmentally } \\
\text { friendly energy based on science and technology }\end{array}$ & $4(9.1)$ & $18(27.7)$ & $22(20.2)$ \\
\hline 3. Following central government policy & $19(43.2)$ & $0(0)$ & $19(17.4)$ \\
\hline
\end{tabular}




\begin{tabular}{|c|c|c|c|}
\hline \multirow{2}{*}{ Main reasons for accepting } & \multicolumn{3}{|c|}{ Sample Responses } \\
\hline & Urban & Rural & Total \\
\hline $\begin{array}{l}\text { 4. Supporting national and regional economic } \\
\text { development and social welfare }\end{array}$ & $5(11.4)$ & $13(20.0)$ & $18(16.5)$ \\
\hline 5. The availability of environmental impact mitigation & $7(15.9)$ & $8(12.3)$ & $15(13.8)$ \\
\hline 6. Supporting local employment & $0(0)$ & $5(7.7)$ & $5(4.6)$ \\
\hline 7. Reducing the use of fossil energy & $0(0)$ & $3(4.6)$ & $3(2.8)$ \\
\hline Total & $44(100)$ & $65(100)$ & 109 (100) \\
\hline
\end{tabular}

Note: Figures in parentheses indicate the percentage (\%).

The rural samples accept the project mostly due to their compliance with government policies, supporting the supply of electricity although some accept the project but disagree with the negative impacts. There are some voices like:

"(It becomes) difficult to do activities, the water is muddy, you can't wash clothes, wash dishes... But the above (government) has wanted to do that plan, so just go along."

"(This is) the state program, it's already done, must agree..."

"As long as the development is safe and does not harm the residents, it may be continued."

Meanwhile, for urban dwellers, project acceptance is more driven by motives to support future electricity supply, support the use of environmentally friendly renewable energy and economic development. Some of the respondents' responses are as follows:

"To meet future dependents in order to meet the electricity needs around Java-Bali."

"Because this is a new breakthrough in the existence of renewable resources. As we know, our natural resources, such as oil and gas, are getting depleted. If there is no solution to the problem, the world will lose its breath. Moreover, Indonesia is a country with many active volcanoes. Geothermal sources in our country are abundant, so we need to take advantage of this for the survival of the future."

The details of the reasons for refusing GPP are mentioned in Table 5 as follows: 1 ) destroying forest ecosystems, water sources and the surrounding environment (37.4\%), 2) disturbing the daily life of the directly affected communities $(19.2 \%), 3$ ) causing river pollution $(17.7 \%), 4)$ causing floods and landslides (12.1\%), 5) disturbing animal habitats and places where they grow (5.1\%), 6) widespread negative impacts $(3.0 \%), 7)$ land cover changes forest $(2.0 \%), 8)$ no mitigation of environmental and social impacts $(2.0 \%), 9)$ threatening tourism sites $(1.0 \%)$, and 10 ) climate change (1.0\%) (see Table 5).

For the rural samples, the reasons for the disruption of daily life due to river pollution are the most dominant, especially because they experienced the disruption of clean water needs, agricultural irrigation and fisheries due to the turbid river water flowing in their area. Several residents of Karang Tengah and Sambirata villages who are directly affected respond as follows:

"The impact is bad for Cilongok residents, making the fishpond full of mud, crop failure and trauma felt by the community..."

"Pity, the residents have trouble getting clean water, muddy pool water, dead fish, loss of laundry business so cannot wash."

"The rice fields becomes infertile because of the sand that enters the rice fields, so the rice harvest fails."

"Afraid of the guards of Mount Slamet; they will be angry."

Meanwhile, for urban samples, the dominant reason for refusing is more because of the damage to the forest ecosystem in the upstream and floods and landslides that occur near residential areas. In addition, the last five reasons were voiced more by the urban sample, namely disruption of animal habitats, biodiversity losses, the extended negative impacts outside the exploitation area, conversion of protected forest land, lack of mitigation, disruption of tourism spots and climate change. A 22 years old female respondent who works as a civil servant and lives outside 
the affected area shows the complete response as follows :

"The unspoiled forest on the slopes of Mount Slamet is very unfortunate to be exploited, will damage the ecosystem, threaten the life of the existing flora and fauna. Then another impact is the damage to springs due to the development, destruction of cultural sites such as sacred sites, then due to forest clearing for the construction of road access to the drilling center, landslides that occur due to construction when the rain comes will cause mudflows in the river to the detriment of residents. This took place in 2017, many residents complained about this, ranging from farmers, chicken breeders, fish cultivators, tofu producers, and other residents complaining about the turbidity of the water."

Table 5. Respondents' reasons for rejecting the GPP project in the Mount Slamet protected forest

\begin{tabular}{|c|c|c|c|}
\hline \multirow[b]{2}{*}{ Reason for Refusing } & \multicolumn{3}{|c|}{ Response } \\
\hline & $\begin{array}{c}\text { Rural } \\
\text { samples }\end{array}$ & $\begin{array}{l}\text { Urban } \\
\text { Samples }\end{array}$ & $\begin{array}{c}\text { Total } \\
\text { samples }\end{array}$ \\
\hline $\begin{array}{l}\text { 1. Damaging forest ecosystems, water sources and } \\
\text { the surrounding environment }\end{array}$ & $9(18.4)$ & $65(43.3)$ & $74(37.4)$ \\
\hline $\begin{array}{l}\text { 2. Disrupting the survival of the surrounding } \\
\text { community }\end{array}$ & $20(40.8)$ & $18(12.0)$ & $38(19.2)$ \\
\hline 3. Causing river pollution & 17 (34.7) & $18(12.0)$ & 35 (17.7) \\
\hline 4. Causing natural disasters, floods and landslides & $3(6.1)$ & $21(14.0)$ & $24(12.1)$ \\
\hline 5. Disturbing animal habitat and forest growth & & $10(6.7)$ & $10(5.1)$ \\
\hline 6. The negative impact is widespread & & $6(4.0)$ & $6(3.0)$ \\
\hline 7. Changes of function of protected forest land & & $4(2.7)$ & $4(2.0)$ \\
\hline $\begin{array}{l}\text { 8. No mitigation of environmental and social } \\
\text { impacts }\end{array}$ & & $4(2.7)$ & $4(2.0)$ \\
\hline 9. Threatening natural tourism attractions & & $2(1.3)$ & $2(1.0)$ \\
\hline 10. Worsening climate change & & $2(1.3)$ & $2(1.0)$ \\
\hline Total responses & 49 (100) & $150(100)$ & $199(100)$ \\
\hline
\end{tabular}

Note: Figures in parentheses indicate the percentage (\%).

Respondents may receive information related to GPP from various media. Table 6 describes the diversity of sources of information obtained by respondents which are divided into five categories. In general, the rural samples access to information about GPP based on category 1 (76.1\%), i.e., seeing firsthand the activities and observing their impacts and / or hearing from relatives who live closely to the affected areas. The next source of information is Category 3, that is, information from a combination of printed, online, social media and direct observation. A few obtain information from printed or online and social media (Category 2). Likewise, very few residents rely on category 4. Meanwhile the urban samples receive information sources from Category 2, i.e., printed media, social media and online media (41.3\%) and only from relatives or friends who are close to the affected areas (Category 3, $28.0 \%$ ). Very few respondents received information directly from the outreach of the GPP project carried out by the government or exploration company.

Table 6. Sources of information accessed by respondents about Baturaden GPP

\begin{tabular}{|l|r|r|r|}
\hline \multicolumn{2}{|c|}{ Category } & \multicolumn{1}{c|}{ Sample } \\
\cline { 3 - 4 } & \multicolumn{1}{|c|}{ WDL } & \multicolumn{1}{c|}{ WDTL } & \multicolumn{1}{c|}{ Total } \\
\hline $\begin{array}{l}\text { 1. } \\
\text { Friends / relatives and / or see for themselves the } \\
\text { impact }\end{array}$ & $89(76.1)$ & $23(14.9)$ & $112(41.3)$ \\
\hline $\begin{array}{l}\text { 2. } \\
\text { A combination of mass media (print), online } \\
\text { media, social media, friends / relatives, and / or } \\
\text { seeing for yourself }\end{array}$ & $20(17.1)$ & $56(36.4)$ & $76(28.0)$ \\
\hline $\begin{array}{l}\text { 3. } \\
\text { Mass media (print), social media, and or online } \\
\text { media }\end{array}$ & $3(2.6)$ & $60(39.0)$ & $63(23.2)$ \\
\hline $\begin{array}{l}\text { 4. } \\
\text { A combination of mass media (print), online } \\
\text { media, social media, seeing for yourself, friends / }\end{array}$ & $4(3.4)$ & $11(7.1)$ & $15(5.5)$ \\
\hline
\end{tabular}




\begin{tabular}{|l|r|r|r|}
\hline \multicolumn{1}{|c|}{ Category } & \multicolumn{1}{|c|}{ Sample } \\
\cline { 2 - 4 } & \multicolumn{1}{|c|}{ WDL } & \multicolumn{1}{c|}{ WDTL } & \multicolumn{1}{c|}{ Total } \\
\hline $\begin{array}{l}\text { relatives, and / or socialization carried out by the } \\
\text { government and / or managing companies }\end{array}$ & & & \\
\hline $\begin{array}{l}\text { 5. Socialization carried out by the government and / } \\
\text { or management companies }\end{array}$ & $1(0.9)$ & $4(2.6)$ & $5(1.8)$ \\
\hline Total & 117 & 154 & $271(100)$ \\
\hline
\end{tabular}

Note : the unit in parentheses is percentage (\%)

\subsection{Factor Analysis}

Seventeen statements in Table 1 were analyzed to determine the respondent's knowledge and attitude towards GPP in the Mount Slamet protection forest. The mulivariate statistical method, factor analysis is used to identify the correlation between the statement items and the resulting factors so that a simpler knowledge and attitude variable is produced. Principal component analysis with varimax orthogonal rotation was used with the help of STATA version 13.0 software. Table 7 presents the results of the rotated factor analysis component matrix. The minimum factor loading value used is 0.50 , so the five statement items in Table 1 , namely $X 3, X 7, X 9, X 12$, and $X 15$, were excluded. This factor loading determines the construct validity of the statements that correlates to factor generated; the closer to 1 is the higher correlation in measuring the factor. The results of the adequacy test of the sample using the Kaiser Mayer-Olkin (KMO) amounted to 0.763 , so that the requirements for the adequacy of the sample to determine the correlation between the independent variables were fulfilled (minimum value 0.5 ). Factor analysis produces four factors that have eigenvalue $>=1$ and these four factors can explain the diversity up to $60 \%$. The reliability test with Cronbach alpha for each factor varied between 0.55 and 0.823 , which show a moderate to high internal consistency of the statement items in the same group. The closer value of Cronbach alpha to 1.0 the higher the measure of the internal consistency of the factor group.

Table 7. Output factor analysis and Cronbach alpha reliability test

\begin{tabular}{|c|c|c|c|c|c|}
\hline Factor & Code/Statement & $\begin{array}{l}\text { Loading } \\
\text { Factor }\end{array}$ & $\begin{array}{c}\text { Diversity } \\
\text { (\%) }\end{array}$ & $\begin{array}{c}\text { Cronbach } \\
\text { alpha }\end{array}$ & $\begin{array}{l}\text { Factor } \\
\text { mean }\end{array}$ \\
\hline \multirow{4}{*}{$\begin{array}{l}\text { Economic } \\
\text { perspective of } \\
\text { protection } \\
\text { forest by } \\
\text { utilizing } \\
\text { geothermal } \\
\text { energy (f1) }\end{array}$} & $\begin{array}{l}\mathrm{X} 1 \text { : Geothermal energy as a } \\
\text { source of new and renewable } \\
\text { energy that is environmentally } \\
\text { friendly. }\end{array}$ & 0.8567 & \multirow[t]{4}{*}{20.64} & \multirow[t]{4}{*}{0.8233} & \multirow[t]{4}{*}{4.5} \\
\hline & $\begin{array}{l}\mathrm{X} 2 \text { : Most of the potential for } \\
\text { geothermal energy is under forest } \\
\text { areas. }\end{array}$ & 0.8024 & & & \\
\hline & $\begin{array}{l}\text { X4: The local government policy } \\
\text { approved the construction of the } \\
\text { Baturraden Geothermal Power } \\
\text { Plant (GPPB). }\end{array}$ & 0.7751 & & & \\
\hline & $\begin{array}{l}\text { X17 : The construction of the } \\
\text { Baturraden GPP project opens job } \\
\text { and business opportunities. }\end{array}$ & 0.6574 & & & \\
\hline \multirow[t]{2}{*}{$\begin{array}{l}\text { Technological } \\
\text { optimism of } \\
\text { geothermal } \\
\text { utilization }(\mathrm{f} 2)\end{array}$} & $\begin{array}{l}\text { X10: The construction of the } \\
\text { Baturraden GPP project does not } \\
\text { reduce the quality of the } \\
\text { environment, especially } \\
\text { biodiversity and water } \\
\text { management. }\end{array}$ & 0.7868 & \multirow[t]{2}{*}{14.89} & \multirow[t]{2}{*}{0.7905} & \multirow[t]{2}{*}{1.33} \\
\hline & $\begin{array}{l}\mathrm{X} 11 \text { : Changes in the color of } \\
\text { water in several river flows that } \\
\text { are upstream in protected forest } \\
\text { areas do not interfere with the }\end{array}$ & 0.8653 & & & \\
\hline
\end{tabular}




\begin{tabular}{|c|c|c|c|c|c|}
\hline Factor & Code/Statement & $\begin{array}{l}\text { Loading } \\
\text { Factor }\end{array}$ & $\begin{array}{l}\text { Diversity } \\
\text { (\%) }\end{array}$ & $\begin{array}{l}\text { Cronbach } \\
\text { alpha }\end{array}$ & $\begin{array}{l}\text { Factor } \\
\text { mean }\end{array}$ \\
\hline & $\begin{array}{l}\text { availability of clean water, } \\
\text { especially toilets and household } \\
\text { needs. }\end{array}$ & & & & \\
\hline & $\begin{array}{l}\text { X16: The construction of the } \\
\text { Baturaden GPP project did not } \\
\text { damage people's agriculture. }\end{array}$ & 0.8078 & & & \\
\hline \multirow{3}{*}{$\begin{array}{l}\text { Environmental } \\
\text { concerns of } \\
\text { geothermal } \\
\text { development }\end{array}$} & $\begin{array}{l}\text { X5: Feel the change in the color of } \\
\text { the water in the Prukut river. }\end{array}$ & 0.8407 & \multirow[t]{3}{*}{13.74} & \multirow[t]{3}{*}{0.6739} & \multirow[t]{3}{*}{3.33} \\
\hline & $\begin{array}{l}\text { X6: Feeling the big flood that } \\
\text { happened recently. }\end{array}$ & 0.8598 & & & \\
\hline & $\begin{array}{l}\text { X8: The threat of erosion and } \\
\text { landslides due to clearing of } \\
\text { protected forest lands. }\end{array}$ & 0.5253 & & & \\
\hline \multirow[t]{2}{*}{$\begin{array}{l}\text { Social } \\
\text { harmony (f } 4 \text { ) }\end{array}$} & $\begin{array}{l}\text { X13: The construction of the } \\
\text { Baturraden GPP project did not } \\
\text { cause conflict between } \\
\text { communities. }\end{array}$ & 0.688 & \multirow[t]{2}{*}{10.74} & \multirow[t]{2}{*}{0.5509} & \multirow[t]{2}{*}{3.5} \\
\hline & $\begin{array}{l}\text { X14: The construction of the } \\
\text { Baturraden GPP project does not } \\
\text { cause conflict between the } \\
\text { community and the managing } \\
\text { company and / or the } \\
\text { government. }\end{array}$ & 0.8376 & & & \\
\hline
\end{tabular}

Table 7 describes the four factors generated from factor analysis. The four factors are then named according to the statement items included in the membership of each factor. These four factors represent different perceptions of the protection forest utilization for geothermal energy as follows: 1) economic perspective of protection forest for geothermal enery (f1), 2) technological optimism of geothermal development that does not harm the quality of life ( $f 2$ ), 3 ) environmental concern of the impact of geothermal development (f3) and 4) social conflict of interests (f4). The f1 factor explains the highest diversity, which is $20.64 \%$ with a Cronbach alpha value of 0.8233 and an average value of 4.5 , indicating the amount of support for geothermal utilization to create employment opportunities. Meanwhile, $\mathrm{f} 4$ is the smallest factor in explaining diversity, contributing only $10.74 \%$, and with a small Cronbach alpha value $(<0.7)$ so it has the lowest reliability coefficient compared to other factor groups.

\subsection{Logistic regression}

In logistic or logit regression analysis, the dependent variable $(Y)$ is the response of the residents whether the geothermal exploration should be continue to the next phase (Q2). If residents agree to continue, they will be given code 1 , whereas if they do not agree, they will be given code 0 . Respondents who answer neither are excluded in this logistic regression analysis. The independent variables explaining this attitude are the the simpler factor variables that describes four perceptions of the GPP project ( $f 1, f 2, f 3$, and $f 4)$ and the socio-demographic variables, namely age, gender, education level and income level. At first we tested whether models for rural and urban samples could be combined into one aggregate model. The Loglikehood Ratio (LR) test showed that both samples had significant different estimates, so we disagregate into two models: rural and urban. The rural model analyzed 87 respondents with a significant overall model seen from Chi2 test of 32.57 and significant at $\alpha<1 \%$. While the urban model observes 125 samples with Chi2 test value of 69.37 and is also significant at $\alpha<1 \%$.

Table 8 shows two factors ( $\mathrm{f} 1$ and $\mathrm{f} 2$ ) are significant at $\alpha<5 \%$ for rural model. Whereas three factors (f1, f2, and f3) are significant at the $\alpha<5 \%$ significance level for urban model. A positive 
coefficient value indicates an increase in the level of this factor increases the probability to continue the GPP project. In both model, the f1 factor (the higher the level of approval for the use of geothermal in forest areas to suply energy and create employment opportunities) and the $\mathrm{f} 2$ factor (the more optimistic that the geothermal techhology do not harm environmental, social and economic quality), the greater the chance to support the continuation of the GPP project. In rural model, the increase in one level of $\mathrm{f} 1$ contributes to the decision to continue GPP by factor of 1.59, ceteris paribus. Whilst, for urban model this $\mathrm{f} 1$ contributes higher by factor of 2.69 , all other are equal. Factor $\mathrm{f3}$ is only significant for urban model, indicating that increase one level of environmental concern of the impact of geothermal exploration reduces the probability to support the GPP in future by factor of 1.42 . There is no socio-demographic variable significantly explained the probability to accept the project in the rural model, while the age variable in the urban model is significant. The negative sign of age variable indicates that the older the respondent, the greater the probability to reject the GPP.

Table 8. Outputs of logistic regression analysis

\begin{tabular}{|c|c|c|c|c|}
\hline \multirow[t]{2}{*}{ Variable } & \multicolumn{2}{|c|}{ Model rural } & \multicolumn{2}{|c|}{ Model urban } \\
\hline & Coefficient (SE) & $P>|z|$ & Coefficient (SE) & $P>|z|$ \\
\hline Constant & $-0.659(1.823)$ & 0.718 & $-0.36(0.458)$ & 0.430 \\
\hline \multicolumn{5}{|l|}{ Attitude factor: } \\
\hline$f 1$ & $1.59(0.488)^{* * *}$ & 0.001 & $2.69(0.619)^{* * *}$ & 0.000 \\
\hline$f 2$ & $0.79(0.395)^{* *}$ & 0.045 & $1.32(0.360)^{* * *}$ & 0.000 \\
\hline f3 & $0.03(0.457)$ & 0.944 & $-1.42(0.383)^{* * *}$ & 0.000 \\
\hline f4 & $0.62(0.421)$ & 0.142 & $-0.65(0.312)$ & 0.080 \\
\hline \multicolumn{5}{|l|}{ Socio-demographic factors: } \\
\hline Age (years) & $0.02(0.028)$ & 0.530 & $-0.06(0.029) * *$ & 0.026 \\
\hline Gender (Male: 1; Female: 0) & $1.34(0.843)$ & 0.112 & $0.92(0.591)$ & 0.119 \\
\hline $\begin{array}{l}\text { Education ( } 1 \text { = not going to } \\
\text { school; } 5=\text { graduating from } \\
\text { college) }\end{array}$ & $-0.001(0.402)$ & 0.998 & $0.46(0.516)$ & 0.377 \\
\hline $\begin{array}{l}\text { Income (1: <UMK, } 3 \text { : } \\
>2 \text { xUMK) }\end{array}$ & $-1.09(0.978)$ & 0.266 & $-0.36(0.458)$ & 0.430 \\
\hline \multicolumn{5}{|l|}{ Statistics } \\
\hline Number of observations & 87 & & 125 & \\
\hline LR chi2(7) & 32.57 & & 69.37 & \\
\hline Prob>chi2 & 0.0001 & & 0.000 & \\
\hline Pseudo R2 & 0.3566 & & 0.4246 & \\
\hline Log likelihood & -29.379 & & -46.994 & \\
\hline
\end{tabular}

Note : ${ }^{* * *}$ significant at $\alpha<1 \%$; ${ }^{* *}$ significant at $\alpha<5 \%$; *significant at $\alpha<10 \%$

\section{Discussion}

This study aims to reveal the social acceptance of residents affected by Baturaden GPP exploration, operating in Mount Slamet protection forest and the factors influence it. Although geothermal is one of the cleanest sources of energy that can contribute to the solution of the present global crisis of climate change, the exploration and drilling operation could create unexpected impacts for the local and the environment in adjacent areas (de Jesus, 2016). Many studies report social acceptance of geothermal energy by local dwellers is a salient barrier that affects other barriers, such as financial, technical, and political risks (Kubota et al. 2013). Some findings of this research confrm other studies and strengthen the knowledge of social acceptance for geothermal energy in protection forests in several ways.

Firstly, while the GPP activity entering the exploration phase, the residents prefer not to continueing drilling activities. The non-acceptance of the geothermal is also found in other protection forests, such as Ciremai geothermal plant in West Java, where about $74 \%$ of the respondents reject the plan (Gizawi et al., 2017). According to Cataldi (1999), the attitude of 
residents towards GPP development will negatively react along with the intensification of drilling activities. These activities usually have impacts on changes in ecosystem function (land, water, flora and fauna), human health (due to environmental pollution), local economy (decreased land productivity and crop failure), and landscape modification that converts certain cultural interests and religious practices with industrial culture. In a study at Mount Salak, West Java, the exploitation of GPP caused losses to the community due to changes in the quality and quantity of clean water and water for agriculture. The value of this loss is estimated at IDR 5.29 million per person (Tampubolon, 2015).

Secondly, this study shows that the majority of rural and urban dwellers prefer not to accept GPP development but their reasons and attitudes are quiet diverse. Some rural inhabitants seem to just accepting the government policy of GPP, although they are aware of the negative impacts of the geothermal exploration that has disrupted their daily livelihood. This leads them to having stronger rejection than urban people who do not have such direct experiences. This relates to syndrome of not in my backyard (NIMBY), which is known for any rejection toward vital facilities establised near the dwellers' sites that could potentially worsen their daily lives (Dear, 1992). The evidence in this research also shows urban dwellers, mostly indirectly affected residents, tend to more relax, "wait and see", of the continuation of the project. Many of them change the attitude from disagreement to be more neutral when the exploration phase takes place. They perceive the GPP as a prospect development of renewable and greener energy than the fossil fuel although they also concern about the negative externality on the biodiversity loss and ecological disasters following the exploration and drilling phase.

Thirdly, this study reveals three significant perceptions about the utilization of protection forest for geothermal energy, classified into economic perspective, technological optimism, and environmental concern. The economic perspective explains the beliefs in the benefits of geothermal energy inside protection forest areas for suplying energy and creating job opportunity. Technological optimism describes perceived new geothermal technology should not disrupt the quality of the environment, social and local economiy. Whilst, environmental concerns is related to perceptions of the threat of floods and landslides due to GPP construction. These factors combined could have profound effects on the probability of residents to accept the GPP development.

The NIMBY syndrome which could hinder this vital facility development, appears within the local stakeholder about its negative externality on quality of life in rural areas. This externality needs to be followed up with disaster mitigation efforts since the beginning of the project. Increasing social acceptance also greatly depends on the extent to which information, participation, cooperation and consolidation in strategic environmental assesment (SEA) related to GPP are manifested in every stage of development activities. As stated by Cataldi (2001), in building the GPP project, the Government and industry need to act in harmony with the dynamic environmental conditions and pay attention to the health, welfare and culture of the local community.

Low social acceptance of GPP does not only occur in developing countries, but also in developed countries. For example in Australia, the problem of low social acceptance is also influenced by the relatively limited coverage of the mass media about GPP, especially related to technological uncertainty, environmental risks, opportunities for environmentally friendly energy to overcome climate change and economic feasibility (Romanach et al., 2015). While in Europe, social acceptance of geothermal is high, but public awareness and perception still need to be improved with education from elementary to tertiary level and the need for comparative studies among local policy makers on the success of GPP development (Kępińska \& Kasztelewicz, 2015). In Chile, GPP development is constrained by a low level of understanding of GPP technology, and the existence of social barriers, such as low trust in the government and industry, belief in the myth of spiritual relationships with volcanoes and the risk of environmental impacts (Payera, 2018). It is important to increase the level of social acceptance by enhancing trust between local communities and geothermal developers/operators and policy makers while scaling down potential conflicts, time delays, and reactions that could lead to increased costs (Karytsas \& Polyzou, 2021). 


\section{Conclusion}

This study reports that Banyumas residents prefer not to support the continuation of Baturaden GPP, operated in Mount Slamet protection forest. The directly affected rural residents living near the project tend to have stronger rejection rate than those who live in urban areas far from the drilling site. This rural attitude is usually related to, as usually indicated by NIMBY (not in my backyard) syndrome. The indirect affected urban inhabitants tend to "wait and see" of the continuation of the project, although they concern about the environmental impacts in the forest sites and in adjacent areas. However, some rural dwellers support the project possibly because they are complying with government policies, although they do not agree with the negative impact on their disrupted livelihood. Whereas, the urban people supporting the GPP is mainly due to prospect of renewable and cleaner energy supply in future. Based on logistic regression analysis, three perspecives of the residents could significantly influence their decisions to support or reject the GPP development, namely: 1) the economic prospective, 2) technological optimism, and 3) environmental concerns.

Considering this research finding, this study suggests two fold measures to increase the social acceptance of GPP development in protection forests. Firstly, the government and company operator should ensure that the exploration and drilling operation at any phase should consider local people needs (e.g. local job creation), prevent the negative impact on the disruption of daily livelihood by using more proper and user friendly technology and or provide monetary compensation for the impacted residents and biodiversity losses in protection forests. These actions would involve significant burdens for the project budget to internalise these external costs, but this could yield external benefits for the project owner, such as saving of labour and shorthening of time for the return investment (Cataldi, 1999). Secondly, it is important to increase people's perceptions and awareness of the actual benefits of GPP for not only for the benefit of certain sectors (electricity production) but also for mitigating the climate crisis. If the target to lower the emision as stated in Indonesia nationally determined commitment (INDC) to be achieved by 2030, increasing public knowledge and awareness about the use of alternative energy to replace conventional energy (petroleum) needs to be more supported.

Author Contributions: Dhifa Qorizki conceived and designed the survey questionnaires and collected the data. Dwiko B. Permadi processed and analysed the data and wrote the paper. Teguh Yuwono and Rohman added materials for the data analysis and writing the paper.

\section{Conflicts of Interest:}

We declare no conflict of interest in conducting and writing this paper.

\section{Acknowledgments:}

We express our sincere thanks for the anonymous reviewers for their valuable suggestion so that this paper can be improved and published. We thank to the respondents both in rural and netizens for their voices regarding the research topic in geothermal development. This research is self-funded.

\section{References}

Ahmad, A., Rashid, M., Omar, A.N., Alam, S.S. (2014). Perceptions on Renewable Energy Use in Malaysia: Mediating Role of Attitude. Jurnal Pengurusan 41, 123-131.

Cataldi, R. (1999). Social acceptance: a sine qua non for geothermal development in the 21st century. Bulletin d'Hydrogiologie, 17, 467-476.

Cataldi, R. (2001). Social acceptance of geothermal projects: problems and costs. In Prociding European Summer School on Geothermal Energy Applications. Oradea/RO, 343-351.

Dear, M. (1992). Understanding and overcoming the NIMBY syndrome. Journal of the American planning association, 58(3), 288-300. https://doi.org/10.1080/01944369208975808

de Jesus, A. C. (2016). Environmental benefits and challenges associated with geothermal power generation. In DiPippo, R. (Ed.) Geothermal Power Generation (pp. 477-498). Woodhead Publishing.https://doi.org/10.1016/B978-0-08-100337-4.00017-6. 
Dowd, A. M., Boughen, N., Ashworth, P., \& Carr-Cornish, S. (2011). Geothermal technology in Australia: Investigating social acceptance. Energy Policy, 39(10), 6301-6307. https://doi.org/10.1016/j.enpol.2011.07.029

Gizawi, A. S., Ritohardoyo, S., \& Haryono, E. H. (2017). Kajian ekologi bentanglahan dan persepsi masyarakat terhadap rencana eksplorasi panas bumi. Majalah Geografi Indonesia, 31(1), 111. https://doi.org/10.22146/mgi.24223

Hoover, W. S., Girmansyah, D., Wiriadinata, H., \& Hunter, J. M. (2009). Exploration of High elevation liana colonies on Mt. Slamet, Central Java, Indonesia. Reinwardtia, 13(1), 45-67. http://dx.doi.org/10.14203/reinwardtia.v13i1.433

Hymans, J. E., \& Uchikoshi, F. (2021). To drill or not to drill: determinants of geothermal energy $\begin{array}{llll}\text { project siting in Japan. Environmental Politics, } & \end{array}$ https://doi.org/10.1080/09644016.2021.1918493

Kalima, T. (2007). Keragaman jenis dan populasi flora pohon di hutan lindung Gunung Slamet, Baturraden, Jawa Tengah. Jurnal Penelitian Hutan dan Konservasi Alam, 4(2), 151-160. https://doi.org/10.20886/jphka.2007.4.2.151-160

Karytsas, S., \& Polyzou, O. (2021). Social acceptance of geothermal power plants. In C. O. Colpan, M. A. Ezan, \& O. Kizilkan (Eds.) Thermodynamic Analysis and Optimization of Geothermal Power Plants (pp. 65-79). Elsevier.

Kępińska, B., and Kasztelewicz, A. 2015. Public Perception of Geothermal Energy in Selected European Countries. In Proceedings World Geothermal Congress, Melbourne, Australia (1925 April 2015).

Kubota, H., Hondo, H., Hienuki, S., \& Kaieda, H. (2013). Determining barriers to developing geothermal power generation in Japan: societal acceptance by stakeholders involved in hot springs. Energy Policy, 61, 1079-1087. https://doi.org/10.1016/j.enpol.2013.05.084

Kusuma, Y.W.C., Astuti, I.P. (2009). Population and Microhabitat Characteristic of Homalomena bellula Schott in Mount Slamet, Central Java, Indonesia. Biodiversitas Journal of Biological Diversity, 10(4), 201-205. https://doi.org/10.13057/biodiv/d100407

Latifah, M., dan Gusmayanti, E. (2012). Optimalisasi Pemanfataan Panas Bumi sebagai Sumber Energi Pembangkit Listrik untuk Mencapai Keamanan Energi. The 2012 ASC Paper Competition Participants. Universitas Indonesia.

Liu, H., Wang, H., Gou, Y., \& Li, M. (2018). Investigation on social acceptance of the geothermal energy utilization in China. Geothermal Resources Council Transactions, 42, 812-824.

Miles, M.B., Huberman, A.M., Saldana, J. (2014). Qualitative Data Analysis: A Methods Sourcebook ( $3^{\text {rd }}$ Edition). SAGE Publication, Inc.

Ministry of Environment (MOE). (2008). Pertimbangan-pertimbangan dalam Penerapan Kajian Lingkungan Hidup Strategis untuk Kebijakan, Rencana dan Program Penataan Ruang. Kementerian Lingkungan.

Ministry of Environment and Forestry (MOEF). (2015). Rencana Strategis Direktorat Pemanfaatan Jasa Lingkungan Hutan Konservasi Tahun 2015-2019. Direktorat Jenderal Konservasi Sumberdaya Alam dan Ekosistem. Kementerian Lingkungan Hidup dan Kehutanan.

Ministry of Energy and Mineral Resources (MEMR). (2015). Rencana Strategis Kementerian Energi dan Sumber Daya Mineral 2015 - 2019. Kementerian Energi dan Sumberdaya Mineral.

Meijaard, E., Dennis, R. A., Saputra, B. K., Draugelis, G. J., Qadir, M. C. A., \& Garnier, S. (2019). Rapid environmental and social assessment of geothermal power development in conservation forest areas of Indonesia. PROFOR, The World Bank.

Payera, S. V. (2018). Understanding social acceptance of geothermal energy: Case study for Araucanía region, Chile. Geothermics, 72, 138-144. https://doi.org/10.1016/j.geothermics.2017.10.014

Reith, S., Kölbel, T., Schlagermann, P., Pellizzone, A., \& Allansdottir, A. (2013). Public acceptance of geothermal electricity production (Deliverable $n^{\circ} 4.4$ Report on public acceptance). GeoElec. http://www.geoelec.eu/wp-content/uploads/2014/03/D-4.4-GEOELEC-report-on-publicacceptance.pdf

Romanach, L., Carr-Cornish, S., \& Muriuki, G. (2015). Societal acceptance of an emerging energy 
technology: How is geothermal energy portrayed in Australian media?. Renewable and Sustainable Energy Reviews, 42, 1143-1150. https://doi.org/10.1016/j.rser.2014.10.088

Setiawan, S. (2012). Energi panas bumi dalam kerangka MP3EI: Analisis terhadap prospek, kendala, dan dukungan kebijakan. Jurnal Ekonomi dan Pembangunan, 20(1), 1-28.

Setiawan, A. R. I. F., Djuwantoko, A. W., Bintari, Y. W. C., Kusuma, S. P., \& MA, I. (2007). Populasi dan Distribusi Rekrekan (Presbytis fredericae) di Lereng Selatan Gunung Slamet Jawa Tengah. Biodiversitas Journal of Biological Diversity, 8(4), 305-308. https://doi.org/10.13057/biodiv/d080412

Simon, H. (2000). Pengelolaan Hutan Bersama Rakyat. Bigraf Publishing.

Suara Merdeka. 2017. Perubahan Hutan Lindung di Gunung Slamet Picu Banjir. Suara Merdeka. https://www.suaramerdeka.com/smcetak/baca/45087/perubahan-hutan-lindung-digunung-slamet-picu-banjir

Tampubolon, B.I. (2015). Analisis Kebijakan Pemanfaatan Energi Panas Bumi sebagai Alternatif Pembangkit Listrik (Master Thesis). Institut Pertanian Bogor.

Widhiono, I. (2015). Diversity of butterflies in four different forest types in Mount Slamet, Central Java, Indonesia. Biodiversitas Journal of Biological Diversity, 16(2), 196-204. https://doi.org/10.13057/biodiv/d160215 